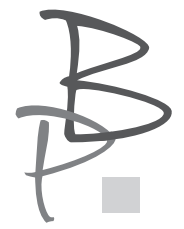

Dobrosława Platt*

Biblioteka Polska POSK w Londynie, Wielka Brytania

\title{
Archiwa Biblioteki Polskiej POSK w Londynie jako źródła do badań biograficznych
}

The archives of the POSK Polish Library in London as a source of biographic research

Abstract: In her article, Dobrosława Platt presents the archives of the POSK Polish Library in London as a source of biographical research. Biographies, i.e. detailed descriptions of the lives of specific figures, have, in her opinion, been particularly popular with readers for a very long time. Even when they were not as yet linked with any genre, and the biographies of famous figures were supposed to reflect only as certain patterns of behaviour, readers would eagerly listen to or rewrite "the lives of famous men" for their own libraries. Frequently, they were not a reliable reflection of a given person's life, but rather a desire to create a model to follow. The researcher also states that after the

* Dobrosława Platt - dr; dyrektor Biblioteki Polskiej POSK w Londynie; autorka wielu artykułów i książek, m.in. Kazania pogrzebowe z przełomu XVI i XVII wieku: z dziejów prozy staropolskiej (1992). 
Second World War many outstanding writers, poets and publicists appeared in Great Britain and continued to create there, publishing their works in exile. It seems that many of them are still on the margins of Polish literature, although they do not deserve it, and by making their biographies it would perhaps allow re-evaluation of their work.

Keywords: bibliographic research, modern history, Polish emigration literature in Great Britain, interpretation.

\section{Od ,żywotów" do biografii - zarys}

Biografie, a więc szczegółowe opisy życia konkretnych postaci, cieszą się szczególną popularnością wśród czytelników od dawna. Nawet wówczas, kiedy nie nadawano im jeszcze gatunkowej przynależności, a życiorysy sławnych, znanych postaci miały służyć jedynie jako pewne wzorce postępowania, to odbiorcy chętnie słuchali lub przepisywali do własnych bibliotek ,żywoty sławnych mężów”. Często były one nie tyle rzetelnym odzwierciedleniem życia danej postaci, ile chęcią stworzenia wzoru do naśladowania.

Kiedy sięgniemy do źródeł, a więc do starożytności, w której gatunek ten się pojawił między innymi w dziele znakomitego rzymskiego historyka, Korneliusa Neposa De viris illustribus (O wybitnych mężach) około 44 roku p.n.e., opisującego zarówno życie wielkich wodzów - obcokrajowców, jak i łacińskich historyków, dostrzec możemy od razu cele, ale i wątpliwości, jakie towarzyszyć mogą tworzeniu biografii jako gatunku.

We wstępie Nepos pisze bowiem, że w opisie i ocenie postaci istotne jest zwrócenie uwagi czytelnika na różnice kulturowe, jakie istnieją między Grekami a Rzymianami, które wpływać mogą na swoiste rozłożenie akcentów w ramach tego, co, a raczej kto może być bohaterem biografii:

[...] w wielu wypadkach to, co według naszych zwyczajów jest stosowne, u Greków uchodzi za niewłaściwe. Któż bowiem z Rzymian krępuje się zabrać ze sobą żonę na przyjęcie? Albo czyja matka rodziny nie zajmuje pierwszego miejsca w domu i nie udziela się towarzysko? W Grecji rzecz ma się zupełnie inaczej, bo kobieta nie bywa tam na przyjęciach, chyba że w gronie rodzinnym, cały czas 
spędza w głębi swego domu, w pokojach dla kobiet, zwanych gynajkonitis, do których żaden mężczyzna poza bliskimi krewnymi nie ma wstępu¹.

Inny autor, najbardziej znany ze swoich dzieł biograficznych i moralizatorskich, Plutarch z Cheronei, który opisał życie pierwszych imperatorów Od Augusta do Witeliusza, stworzył również dzieło o Żywotach sławnych mężów. Zestawia w nim życiorysy wybitnych Greków z życiorysami wybitnych Rzymian, na przykład oratorów: Demostenesa i Cycerona lub wodzów - Aleksandra Wielkiego i Cezara ${ }^{2}$. Z tego zestawienia ,par biografii powstaje historia Grecji i Rzymu od czasów mitycznych, od czasów Tezeusza i Romulusa aż do końca obu republik, do Filopojmena w Grecji, a morderców Cezara i Antoniusza w Rzymie"3. Plutarch opisuje jednak nie tylko ludzi cnotliwych, którzy mogliby stanowić wzór dla potomnych, ale także ludzi występnych, jak Demetriusz Poliorcetes lub Antoniusz, „byleby to były natury zdolne do olbrzymich porywów i miały piętno tragicznej wielkości”, ponieważ te charaktery winny być przykładami odstraszającymi.

Biografie męczenników, Ojców Kościoła, świętych pojawiają się od średniowiecza, koncentrując się również nie tyle na opisaniu prawdziwego życia, ile na propagowaniu życia pobożnego, co znajduje ukoronowanie w Złotej legendzie Jakuba de Voragine (XIII wiek), w której opowieści fantastyczne i niezwykłe są włączone na równych prawach $\mathrm{z}$ autentycznymi wydarzeniami w życiorysy postaci. Ten hagiograficzny zapis nie byłnowością, ponieważ podobnie starożytni autorzy opisywali egzystencję imperatorów oraz dowódców wojskowych. Średniowiecze wprowadza także biografie kobiet, głównie świętych, które podobnie jak uczeni mężowie, tworzyły znakomite dzieła, jak Hrotswitha (X wiek), autorka opowieści poetyckich, komedii, wzorowanych na Terencjuszu oraz poematu biograficznego o czynach Ottona Wielkiego czy znakomitej mistyczki, poetki i kompozytorki, jak Hildegarda z Bingen (XI/XII wiek) ${ }^{4}$.

1 K. Nepos, Żywoty wybitnych mężów. Edycja komputerowa: www.zrodla.historyczne.prv.pl

2 Plutarch z Cheronei, Żywoty sławnych mężów w zrewidowanym przekładzie F. N. Golańskiego z dodatkiem trzech żywotów w przeróbce Ign. Krasickiego z wstępem i uwagami Tadeusza Sinki, Kraków [1920]. Biblioteka Narodowa, Seria II, nr. 3, s. XIII.

3 Tamże, s. XIV.

4 Theoderic of Echternach, Godfrey of Disibodenberg, Vita Sancte Hildegardis, ok. 1180. 
Giovanni Boccaccio w swoim dziele De mulieribus claris (O stynnych kobietach), około roku $1361^{5}$, opisuje sylwetki ponad stu wybitnych kobiet starożytności i średniowiecza, rezygnując przy tym z przywołania żywotów świętych. Biografie te jednak mają nadal niezwykle silny rys dydaktyczny i moralizatorski, a wiarygodność źródeł nie ma dla autora większego znaczenia.

Dopiero Giorgio Vasari wprowadził w utworze zatytułowanym Żywoty najsłynniejszych malarzy, rzeźbiarzy i architektów (1550) zasadniczą zmianę w stylu tworzenia biografii, starając się odbiorcę przede wszystkim poinformować o życiu prezentowanych przez siebie postaci, ale także powiązać dzieła artystów z ich osobowościami. Twórczość artystyczna jest bowiem związana z życiorysem artysty i jego środowiskiem. Źródła stylu artysty należy szukać w jego życiu i charakterze. To wówczas pojawia się przekonanie, że twórcą dzieła doskonałego może być tylko szlachetny człowiek, ponieważ dzieło sztuki jest odzwierciedleniem duszy artysty.

Jednak już nieco wcześniej ogłoszone zostało dzieło Vipery $O$ pisaniu żywotów sławnych mężów, w którym pojawiły się pierwsze zasady pisania biografii. Przedmiotem jej powinno być opisanie życia i działalności wybitnej jednostki, a celem wyjaśnienie pobudek jej postępowania oraz wydobycie odpowiednich wniosków dla czytelnika.

Za pierwszą nowoczesną biografię uważa się Jamesa Boswella The life of Samuel Johnson (1791). Ponieważ to w tym dziele autor przywołuje badania archiwalne, relacje współczesnych i wywiady z nimi, starając się dokładnie opisać różne aspekty życia Johnsona i jego charakter. Ta zasada biograficzna obowiązuje do dzisiaj.

Biografię jako gatunek w roku 1918 zrewolucjonizował Lytton Strachey, publikując Eminent Victorians. W dziele tym opisał życie czterech bohaterów epoki wiktoriańskiej: kardynała Manninga, Florence Nightingale, Thomasa Arnolda i generała Gordona. Opowiadając o nich, Strachey obalał mity, które powstały wokół tych postaci, kiedy traktowani byli jak narodowi bohaterowie. Autor przywoływał różnorodne dokumenty i argumenty, jednocześnie używając atrakcyjnego stylu.

Strachey stworzył nową szkołę pisania biografii, w której istotna była nie tyle pochwała postaci, ile właśnie dekonstruowanie mitów narosłych wokół nich,

5 I. Grześczak, Przedmowa, [w:] G. Boccaccio, O stynnych kobietach, Warszawa 2013, s. $13-14$. 
naukowa analiza życia i działalnosci, ale także wprowadzanie fikcji na przykład w formie prawdopodobnych dialogów. Jego styl przejęli między innymi: Gamaliel Bradford, André Maurois, Emil Ludwig. Robert Graves w biograficznym dziele Ja, Klaudiusz (1934) rozwinął styl demaskującej mit biografii.

Ten pobieżny przegląd biografii, które w ciągu wieków ukształtowały gatunek, szkicuje tło, które pozwala nam odnieść się do współczesności i wyciągnąć wnioski.

Zarówno w XX, jak i w XXI wieku, na rynku wydawniczym pojawia się ogromna ilość biografii. Uwzględniają one wszystkie style biografii, jakie dotąd się pojawiły. Biografie, oparte na wiarygodnych źródłach, konfrontowanych opiniach, ale także bezkrytyczne, nieraz pisane na zlecenie samych zainteresowanych. Są to zarówno dzieła poświęcone poszczególnym osobom, jak i biografie zbiorowe, kiedy autor przyjmuje konkretne kryterium lub cel, którym odpowiadać będą życiorysy poszczególnych osób, pojawiają się także słowniki biograficzne.

W ostatnim czasie coraz bardziej poszerza się grupa osób, których życie jest opisywane. Nie tylko władcy, politycy, dowódcy wojskowi, ale także pisarze, działacze społeczni, sportowcy, aktorzy, piosenkarze i wiele innych osób doczekało się swoich biografii. W wielu wypadkach biografia opisuje jedynie część życia postaci, ponieważ jest to nadal osoba żyjąca i działająca. Ten typ zapisu spełnia raczej cele marketingowe niż naukowe i jest zdecydowanym zerwaniem z obowiązującą zasadą, że opisywać można jedynie tych, których życie stanowi już zamkniętą całość - tylko wówczas bowiem można zastosować właściwe kryteria, zmierzające do obiektywnego opisu.

Podsumowując, można przywołać wnioski, które sformułował znany polski historyk i biograf, prof. Roman Wapiński:

Celem badań biograficznych jest odkrycie pewnych regularności losów ludzkich, obrazu życia społecznego tkwiącego w świadomości poszczególnych osób, pozyskanie informacji odnośnie do konkretnych wydarzeń, istotnych w jego życiu. Ważne jest także badanie tzw. momentów krytycznych w życiu człowieka, często przełomowych, które wiele zmieniły w życiu osobistym, wpłynęły pobudzająco lub hamująco na pewne sfery. Badania biograficzne odkrywają wreszcie, jak otoczenie społeczne i warunki historyczne, polityczne, kulturotwórcze, ekonomiczne kształtują przebieg ludzkiego życia lub jego istotnej części, na przykład 
działalności politycznej, pisarskiej. W każdej biografii pojawiają się wątki psychologiczne, społeczne, edukacyjne, ekonomiczne, geograficzne, historyczne, polityczne. Śledzenie tych wątków - jednego, dwóch lub trzech - ich wzajemnego wpływu na siebie ujawnia wzajemne zależności, przyczyny i skutki określonych zdarzeń w życiu człowieka, cenione wartości itp. ${ }^{6}$

\section{Archiwa pisarzy w Bibliotece Polskiej POSK w Londynie - prolegomena}

W pisaniu rzetelnych, krytycznych biografii archiwa odgrywają istotną rolę. Autor biografii nie może jednak skupiać się na poszukiwaniu jedynie archiwum osoby, o której pisze. Materiały bowiem jej dotyczące znajdują się także w zbiorach innych osób: rodziny, przyjaciół, wrogów, kolekcjonerów. Tylko wówczas można odtworzyć w miarę wiarygodny obraz postaci, kiedy próbuje się dotrzeć do różnych informacji w potrzebie konfrontowania ich, sprawdzania.

W przypadku polskich emigrantów z okresu drugiej wojny światowej poszukiwania archiwalne są szczególnie utrudnione. Część bowiem materiałów mogła pozostać w Polsce, część znajduje się w archiwach różnych państw (rosyjskich, rumuńskich, węgierskich, francuskich, brytyjskich, amerykańskich $\mathrm{i}$ in.), część w polskich instytucjach emigracyjnych.

Biblioteka Polska POSK w Londynie, która powstała w 1942 roku jako instytucja rządu polskiego na emigracji, zgromadziła ponad dwa tysiące jednostek archiwalnych. Pośród nich są archiwa instytucji emigracyjnych i archiwa różnych osób. Ponieważ coraz częściej pojawiają się biografie pisarzy, także pisarzy emigracyjnych, chciałabym tutaj skupić się jedynie na przeglądzie wybranych archiwów pisarzy emigracyjnych, które znajdują się w Bibliotece Polskiej. Ponad pięćdziesiąt jednostek, nieraz bardzo rozbudowanych, to archiwa pisarzy lub poetów - bardziej lub mniej dzisiaj znanych (często też zapomnianych). Wielu z nich nie doczekało się do dzisiaj biografii, a niektórzy nie są odnotowani w ciągle rozbudowywanych hasłowo słownikach pisarzy polskich.

6 Podaję za: W. Wojdyło, A. Fordoński, Refleksje historiograficzne Profesora Romana Wapińskiego odnośnie do „Biografistyki w Polsce”, „Dzieje Najnowsze” 2016, R. XLVIII, nr 3, s. 146. 
Takim najbardziej spektakularnym przypadkiem jest Kazimierz Wierzyński, urodzony w Drohobyczu w 1894 roku, zmarły w Londynie w 1969 roku: poeta, prozaik, eseista, popularny wśród polskich emigrantów, znany i ceniony zwłaszcza przed wojną w Polsce, po wojnie w kraju znajdujący się na indeksie autorów zakazanych. Po 1989 roku powoli wraca do polskiej świadomości kulturalnej. W wielu miastach pojawiły się ulice jego imienia, a od 2014 roku. Stowarzyszenie Dziennikarzy Polskich przyznaje nagrodę im. Kazimierza Wierzyńskiego za wybitne dzieła z dziedziny dziennikarstwa sportowego. W dwudziestą rocznicę śmierci twórcy, na falach Radia Wolna Europa, wykonał piosenkę poświęconą mu zatytułowaną Kazimierz Wierzyński, bard czasów Solidarności, Jacek Kaczmarski. Mimo coraz większego zainteresowania badaczy twórczością Wierzyńskiego, mimo wielu rozproszonych artykułów naukowych i krytycznych, nadal nie doczekał się on biografii ${ }^{7}$, choć niewątpliwie samo życie Wierzyńskiego było bardzo interesujące i miało znaczący wpływ na całą jego twórczość. Biblioteka posiada najpełniejsze archiwum pisarza, przekazane przez jego żonę, Halinę ${ }^{8}$, choć niestety i w nim są znaczące luki, będące głównie wynikiem usuwania przez żonę części materiałów. Są w nim jednak zarówno kalendarze z notatkami, zeszyty z adresami, korespondencja prowadzona z różnymi osobami i instytucjami, wywiady i rozmowy radiowe oraz rękopisy, maszynopisy twórczości oraz fotografie. Podobnie, jak w przypadku innych osób, materiały Wierzyńskiego znajdują się także w innych miejscach. Między innymi tłumaczenie jego sztuki na język angielski Comrade October. A Play in Three Acts, którego autorem jest Norbert Guterman ${ }^{9}$, stanowi odrębną jednostkę w zbiorach rękopisów. O tym tłumaczeniu nie ma informacji w dorobku Wierzyńskiego. Listy do Mieczysława Grydzewskiego (ok. 400 szt. ${ }^{10}$ znajdują się w zbiorze Grydzewskiego. To w tych listach pojawiają się interesujące informacje dotyczące rodziny poety, z której ocalał jego bratanek, Stanisław Wierzyński, który w 1945 r. był w obozie w Murnau.

7 Trudno uznać za biografię publikację Anny Nasiłowskiej pt. Kazimierz Wierzyński, wydaną przez Oficynę Wydawniczą Interim w 1991 roku, w serii „Sylwetki Pisarzy Emigracyjnych”.

8 BPL RPS 1360/1-9.

9 BPL RPS 179.

10 BPL RPS 768. 
Redaktor „Wiadomości” będzie pośredniczył w kontakcie między Kazimierzem a Stanisławem.

Zbiór materiałów innego znakomitego poety, skamandryty, eseisty i dyplomaty, Stanisława Balińskiego (ur. 1898 w Warszawie, zm. 1984 w Londynie), znajduje się w archiwum dyplomaty, historyka, badacza dziejów Europy Wschodniej i kolekcjonera, Bolesława Szcześniaka (ur. 1908 w Polskiej Woli, zm. 1996). Tutaj jest korespondencja Balińskiego i inne jego materiały ${ }^{11}$. Pod inną sygnaturą są 3 kalendarze z zapiskami ${ }^{12}$. W zbiorze Szcześniaka jest również fragment archiwum innego dramatopisarza, prozaika i recenzenta teatralnego, Waclawa Grubińskiego (ur. 1883 w Warszawie, zm. 1973 w Londynie) ${ }^{13}$. W 1936 roku został on odznaczony Złotym Wawrzynem Akademickim Polskiej Akademii Literatury, w 1939 otrzymał nagrodę Polskiej Akademii Literatury im. Augusta Popławskiego. Jako autor opublikowanej w 1921 roku komedii Lenin w styczniu 1940 roku został we Lwowie aresztowany przez NKWD, skazany na karę śmierci, zamienioną na 10 lat łagru, uwolniony po układzie Sikorski-Majski, podjął pracę w ambasadzie RP w Kujbyszewie. Od 1943 zamieszkał w Londynie, był współzałożycielem Związku Pisarzy Polskich na Obczyźnie i publicystą związanym z „Wiadomościami” Mieczysława Grydzewskiego. W PRL jego nazwisko objęte było cenzurą i całkowitym zakazem publikacji. W zbiorze Szcześniaka znajduje się autograf jego dzieła $W$ czerwonej pajęczynie $e^{14}$ oraz korespondencja ${ }^{15}$. Grubiński ma ponadto własne archiwum, w którym znajdziemy czystopisy i bruliony różnych jego prac oraz notatki, rękopisy i maszynopisy utworów teatralnych, a także korespondencję i dziennik ${ }^{16}$. W jego archiwum są również materiały dotyczące Głównej Komisji Skarbu Narodowego RP, do której został powołany przez prezydenta RP, Augusta Zaleskiego, materiały dotyczące Stowarzyszenia Pisarzy Polskich $\mathrm{i}$ inne materiały warsztatowe ${ }^{17}$. Archiwum Grubińskiego liczy ok. 4500 kart rę-

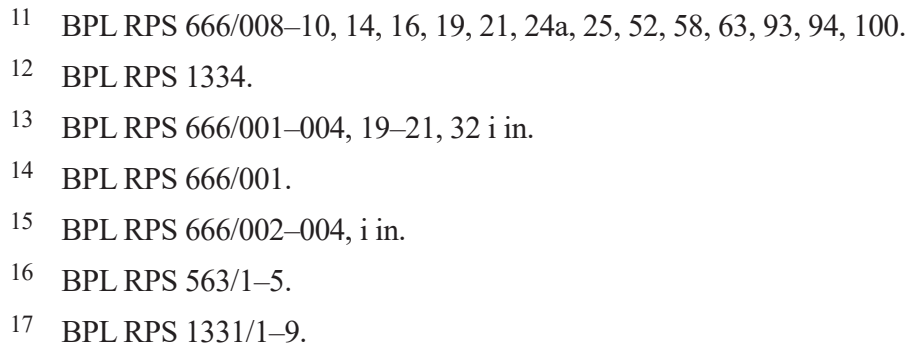


kopisów i maszynopisów. Wydaje się, że stanowi właściwą podstawę do stworzenia biografii popularnego w okresie przedwojennym autora.

Biblioteka Polska w Londynie nie posiada archiwum znakomitego poety, satyryka, eseisty, publicysty i dyplomaty Jana Lechonia (ur. 1899 w Warszawie, zm. 1956 w Nowym Jorku); jest tutaj natomiast autograf jego Dzienni$k o ́ w^{18}$ oraz autografy 28 wierszy ${ }^{19}$, na których pojawiają się notki redakcyjne, poczynione prawdopodobnie ręką Grydzewskiego; jest także taśma z nagraniem ostatniej audycji RWE z jego udziałem z 6 czerwca 1956, a także wspomnienie o spotkaniu z Bernardem Shawem ${ }^{20}$. Przy pracach nad biografią tego autora zapewne warto sięgnąć również do tego zbioru.

Mniej dzisiaj znany pisarz, poeta i aktor scen warszawskich, lwowskich i krakowskich Józef Relidzyński (ur. 1886 w Kielcach, zm. 1964 w Dartford) również ma w Bibliotece swoje archiwum. Podczas pierwszej wojny światowej był w Legionach, a w 1920 roku pełnił funkcję sekretarza i referenta prasowego w delegacji do rokowań polsko-radzieckich w Mińsku. Po wojnie zamieszkał w Londynie, włączając się w życie emigracji (był członkiem Związku Pisarzy Polskich na Obczyźnie). Debiutował w 1904 opowiadaniem W godzine smutku i tęsknoty („Dziennik Poznański”), cztery lata później opublikował tom poezji. Jest między innymi autorem Pieśni Legionów („Okwieciła się dziś ziemia wiosną...”) oraz Roty Pitsudczyków, która powstała na wieść o wywiezieniu Józefa Piłsudskiego do więzienia w Magdeburgu. Do jego legionowych pieśni często komponowano muzykę. Archiwum Relidzyńskiego liczy ok. 500 kart rękopisów i maszynopisów; pośród utworów jest między innymi „Dama pikowa” - nowela fantastyczna ${ }^{21}$.

Kolejnego dyplomaty, legionisty, ale także pisarza i poety archiwum mieści się w zbiorach londyńskich. Archiwum Xawerego Glinki (ur. 1890 w Kijowie, zm. 1957 w Beckenham) 22, który od 1927 roku był attaché prasowym w Belgradzie, Rydze i Helsinkach, a w 1939 r. został zastępcą naczelnika wydziału prasowego Ambasady RP w Paryżu, zawiera wiele dokumentów urzędowych doty-

\footnotetext{
18 BPL RPS 191.

19 BPL RPS 233.

20 BPL RPS 961

21 BPL RPS 230, 245/1-14.

22 BPL RPS 786/1-15.
} 
czących działalności wojskowej, dyplomatycznej i dziennikarskiej, jak również materiały dotyczące jego twórczości literackiej i dziennikarskiej, korespondencję i dokumenty osobiste. Około dwa tysiące kart stanowi dość znaczący materiał, który może służyć do opracowania biografii tej interesującej postaci.

Biografie piszących na emigracji kobiet powstają jeszcze rzadziej niż biografie piszących mężczyzn, choć i to się powoli zmienia. W londyńskiej Bibliotece znajdują się materiały pisarek i poetek, które po drugiej wojnie światowej pozostały na wychodźstwie.

Nie pojawiła się dotąd monografia Zofii Kozarynowej (ur. 1890 w Warszawie, zm. 1992 w Laxton Hall w Wielkiej Brytanii), mimo że jej archiwum ${ }^{23}$ jest w Bibliotece Polskiej. Znana już w latach dwudziestych XX wieku pisarka, choć publikowała u Gebethnera i Wolffa pod męskim pseudonimem - Tadeusz Brudzewski, wiele nowel i opowiadań ogłosiła na łamach „Rzeczypospolitej”. Studiowała na Sorbonie, pracowała jako lektorka języka polskiego i wykładowca literatury polskiej na Uniwersytecie w Turynie. Po wojnie zamieszkała w Wielkiej Brytanii, gdzie publikowała w czasopismach emigracyjnych felietony, pisała również utwory dla dzieci i wydawała przekłady z literatury włoskiej i angielskiej. Jej archiwum zawiera około 4800 kart, w tym 750 listów; są w nim maszynopisy i rękopisy wierszy i nowel, materiały warsztatowe, przekłady z włoskiego, pogadanki dla RWE, kalendarze, zeszyty, a także korespondencja. A listy wymieniała z Jędrzejem Giertychem, Marianem Hemarem, Stanisławem Kosciałkowskim, Marianem Kukielem, Herminią Naglerową, Zygmuntem Nowakowskim, Józefem Wittlinem.

Również znana od lat dwudziestych XX w. przede wszystkim jako autorka słuchowisk, nadawanych w Polskim Radiu, Zofia Bohdanowiczowa (ur. 1898 w Warszawie, zm. 1965 w Toronto) ma swoje archiwum ${ }^{24}$ w Bibliotece Polskiej. Po wojnie publikowała w prasie emigracyjnej, zamieszczając w niej własne wiersze i przekłady z poezji francuskiej i angielskiej. Od 1960 roku mieszkała w Kanadzie. W jej archiwum są zarówno utwory poetyckie, satyryczne, prozatorskie i także korespondencja.

Autorka powieści i sztuk teatralnych, historyk sztuki, która ukończyła studia na Uniwersytecie Jagiellońskim w 1921 roku, a potem kontynuowała je

24 BPL RPS 357, 1304. 
w Budapeszcie, Berlinie i Paryżu - Stefania Zahorska (ur. 1890 w Krakowie, zm. 1961 w Londynie) pozostawiła materiały do jej życia i twórczości. Zamieszkała w Londynie w 1941 roku. W jej archiwum ${ }^{25}$, które zawiera około 3500 kart są dokumenty osobiste, pamiętniki, korespondencja i maszynopisy, bruliony, materiały warsztatowe twórczości. Mimo opublikowania jej Wyboru pism ... ${ }^{26}$ nadal nie ma biografii.

Należy wspomnieć również o tych pisarzach, których archiwa, znajdujące się w Bibliotece Polskiej w Londynie, stały się już owocnym źródłem do powstania biografii życia i twórczości. Pośród nich są: Zygmunt Nowakowski, Sergiusz Piasecki, Ferdynand Goetel, Aleksander Janta-Połczyński.

Zygmunt Nowakowski (właśc. Zygmunt Tempka, ur. 1891 w Krakowie, zm. 1963 w Londynie), pisarz, felietonista, dziennikarz, aktor, reżyser teatralny, dyrektor Teatru im. J. Słowackiego w Krakowie, doktor filologii polskiej. Od 1939 na emigracji. W jego archiwum są dokumenty osobiste, korespondencja, materiały warsztatowe, fotografie, materiały dotyczące pracy w RWE oraz rękopisy i maszynopisy twórczości ${ }^{27}$. Jego biografię - także na podstawie archiwum Reemigrejtan. Kiedy Zygmunt Nowakowski wróci wreszcie do Krakowa? (Wydawnictwo Libron, 2019) opublikował niedawno Paweł Chojnacki.

Archiwum Sergiusza Piaseckiego (ur. 1901 w Lachowiczach, zm. 1964 w Penley) ${ }^{28}$, pisarza, publicysty, oficera wywiadu, żołnierza Armii Krajowej, zawierające dokumenty osobiste, dziennik, materiały warsztatowe oraz autografy lub maszynopisy utworów, było wykorzystywane przez obu biografów pisarza: Ryszarda Demela ${ }^{29}$ i Krzysztofa Polechońskiego ${ }^{30}$. Podobnie archiwum Ferdynanda Goetla (ur. 1890, zm. 1960 w Londynie), w którym znajdują się jego utwory, artykuły, a także niepublikowane fragmenty pamiętnika, było jednym ze źródeł opublikowanej przez Krzysztofa Polechońskiego biografii pisarza ${ }^{31}$.

25 BPL RPS 1122/1-4, 1121, 1123.

26 S. Zahorska, Wybór pism. Reportaże, publicystyka, eseje, Warszawa 2010.

27 BPL RPS 1255/1-14.

28 BPL RPS 247, 363, 364, 401,422, 672,1283.

29 BPL R. Demel, Sergiusz Piasecki (1901-1964). Życie i twórczość, Warszawa 2001.

30 K. Polechoński, Żywot człowieka uzbrojonego. Biografia, twórczość i legenda literacka Sergiusza Piaseckiego, Warszawa 2000.

31 K. Polechoński, Pisarz w czasach wojny i emigracji. Ferdynand Goetel i jego twórczość w latach 1939-1960, Wrocław 2012. 
Aleksander Janta-Polczyński (ur. 1908 w Poznaniu, zm. 1974 na Long Island), poeta, prozaik, reportażysta. Przed wojną w „Wiadomościach Literackich" publikował reportaże ze swoich podróży do Chin, Japonii, Etiopii, Indii, Syjamu, Mongolii i in. Od 1944 roku był przydzielony do 1. Dywizji Pancernej, w której pełnił funkcję korespondenta wojennego. Po wojnie zamieszkał w USA. Opublikował 23 tomy poezji, 10 tomów reportaży, dwa dramaty, trzy powieści, siedem tomów szkiców i esejów; cztery jego książki opublikowane zostały w języku angielskim, poza tym wydał wiele artykułów, szkiców i felietonów. W zbiorach Biblioteki londyńskiej znajduje się maszynopis jego opowiadań z tomu Flet i apokalipsa ${ }^{32}$, a także materiały do działalności społeczno-kulturalnej w USA i w innych miejscach ${ }^{33}$. Franciszek Palowski, autor pierwszej biografii pt. Aleksander Janta-Połczyński. Ballada o wiecznym szukaniu, (Warszawa - Kraków, 1990), korzystał głównie z archiwum prywatnego pisarza ${ }^{34}$.

Po drugiej wojnie światowej wielu znakomitych pisarzy, poetów, publicystów osiadło w Wielkiej Brytanii i tu, mimo licznych przeciwności, tworzyło nadal, wydając swoje utwory głównie w wydawnictwach emigracyjnych. Można jednak odnieść wrażenie, że ciągle jeszcze wielu z nich znajduje się na marginesie polskiej literatury (kultury). Powodów tego stanu rzeczy jest wiele, być może jednak powrót po latach do dzieła ich życia może mieć głębszy sens. Utrwalenie w postaci biografii czy monografii problemowej, a nawet obszernego studium rozpoznań dokonanych na podstawie archiwaliów przechowywanych w Bibliotece Polskiej w Londynie pozwoliłoby uczynić krok na drodze do całościowej oceny dzieła lub jej rewizji.

32 BPL RKS 240.

33 BPL RKS 243/1-5/d.

34 Kolejna biografia ukazała się w 2014 r.: M. Folega, Życie na świat otwarte. Aleksander Janta-Połczyński (Tuchola 2014). 


\section{Bibliografia}

Demel R., Sergiusz Piasecki (1901-1964). Życie i twórczość, Warszawa 2001.

Folega M., Życie na świat otwarte. Aleksander Janta-Połczyński, Tuchola 2014.

Grześczak I., Przedmowa, [w:] G. Boccaccio, O słynnych kobietach, Warszawa 2013.

Nasiłowska A., Kazimierz Wierzyński, Warszawa 1991.

Nepos K., Żywoty wybitnych mężów. Edycja komputerowa: www.zrodla.historyczne.prv.pl.

Plutarch z Cheronei, Żywoty sławnych mężów w zrewidowanym przekładzie F. N. Golańskiego, z dodatkiem trzech żywotów w przeróbce Ign. Krasickiego, z wstępem i uwagami T. Sinki, Kraków [1920].

Polechoński K., Pisarz w czasach wojny i emigracji. Ferdynand Goetel i jego twórczość w latach 1939-1960, Wrocław 2012.

Polechoński K., Żywot człowieka uzbrojonego. Biografia, twórczość i legenda literacka Sergiusza Piaseckiego, Warszawa 2000.

Wojdyło W., Fordoński A., Refleksje historiograficzne Profesora Romana Wapińskiego odnośnie do „Biografistyki w Polsce”, „Dzieje Najnowsze” 2016, R. XLVIII, nr 3.

Zahorska S., Wybór pism. Reportaże, publicystyka, eseje, Warszawa 2010. 